Syntax Literate : Jurnal Ilmiah Indonesia p-ISSN: 2541-0849

e-ISSN : 2548-1398

Vol. 6, No. 12, Desember 2021

\title{
PENYEBARAN KEPEMILIKAN, LIKUIDITAS, DAN NILAI PERUSAHAAN: BUKTI DARI INDONESIA
}

\section{Syaipul Malik Ibrahim, Dewi Hanggraeni}

Fakultas Ekonomi dan Bisnis, Universitas Indonesia (UI) Jakarta, Indonesia

Email: syaipul.malik81@ui.ac.id,dewi_hanggraeni@yahoo.com

\begin{abstract}
Abstrak
Penelitian ini bertujuan untuk menyelidiki hubungan antara penyebaran kepemilikan, likuiditas, dan nilai perusahaan menggunakan sampel dari 225 Perusahaan pada kondisi pasar di Bursa Efek Indonesia ("BEI") sejak 2014 hingga 2019. Penelitian ini menguji penyebaran kepemilikan yang diukur dengan free float, likuiditas sebagai diukur dengan Amihud Illiquidity, nilai perusahaan yang diukur dengan Tobin's Q, dan total aset, rasio laba operasi terhadap harga, rasio leverage keuangan, laba operasi terhadap aset, relative bid-ask spread, turnover, depth, tingkat pengembalian saham, dan tingkat pengembalian aset sebagai variabel kontrol. Penelitian ini menggunakan data panel, yang merupakan kombinasi data cross-section dan time-series dari datastream Thomson Reuters. Penelitian ini menunjukkan bahwa free float berhubungan negatif dengan likuiditas saham dan nilai perusahaan sedangkan likuiditas saham berhubungan positif dengan nilai perusahaan. Temuan kami tidak hanya konsisten dengan beberapa penelitian sebelumnya dalam kaitannya dengan penyebaran kepemilikan yang memiliki hubungan negatif antara Tobin's Q dan penyebaran kepemilikan yang berdampak negatif terhadap likuiditas saham, tetapi juga dapat berfungsi sebagai pengingat bagi investor bahwa saham yang likuid mungkin tidak memberikan pengembalian yang positif.
\end{abstract}

Kata Kunci: penyebaran kepemilikan; free float; amihud illiquidity; nilai perusahaan; tobin's Q

\section{Abstract}

This study aims to investigate the relationship between disperse of ownership, liquidity, and firm value using a sample of 225 Companies on Indonesia Stock Exchange (IDX) market since 2014 until 2019. The study deals with disperse of ownership as measured by free float, liquidity as measured by Amihud illiquidity, firm value as measured by Tobin's $Q$, and total assets, operating income to price ratio, financial leverage ratio, operating income on assets, relative bid-ask spread, turnover of stock, depth of stock, stock return, and return on assets as control variables. This study uses panel data, which is a combination of cross section and time series data from Thomson Reuters data stream. This study indicated that free float is negatively associated with liquidity of stock and both firm value while liquidity of stock is positively associated with firm value. This finding is not only consistent with some prior research in relation to disperse of ownership have a

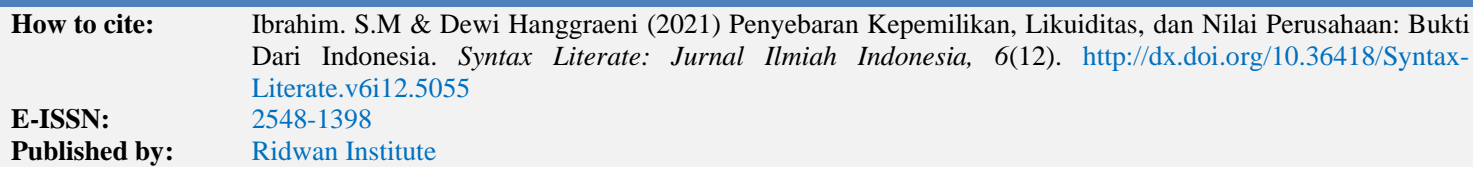


negative correlation with Tobin's $Q$ and disperse of ownership negatively impact liquidity of stock, but also can serve as a reminder for investors that liquid stock may not provide positive returns.

Keywords: disperse of ownership; free float; amihud illiquidity: firm value; tobin's $Q$

Received: 2021-11-20; Accepted: 2021-12-05; Published: 2021-12-20

\section{Pendahuluan}

PT Bursa Efek Indonesia ("PT BEI"), menurut undang-undang Pasar Modal Nomor 8 Tahun 1995 adalah pihak yang menyelenggarakan dan menyediakan sistem dan/atau sarana untuk mempertemukan penawaran jual dan beli efek pihak-pihak lain dengan tujuan memperdagangkan efek di antara mereka. PT BEI selaku Self-Regulatory Organization ("SRO") menjalankan amanat tercantum dalam undang-undang tersebut dengan menerbitkan keputusan Nomor: KEP-00059/BEI/07-2019 pada tanggal 22 Juli 2019 tentang "Peraturan No. I-V tentang ketentuan khusus pencatatan saham dan efek bersifat ekuitas selain saham di papan akselerasi yang diterbitkan oleh perusahaan tercatat". Dalam lampiran perubahan aturan tersebut pada angka V.1. dijelaskan bahwa agar perusahaan tercatat tetap dapat tercatat dalam bursa maka jumlah saham yang dimiliki oleh pemegang saham bukan pengendali dan bukan pemegang saham utama paling sedikit adalah $7,5 \%$.

Dasar persentase kepemilikan dianggap penting karena kemampuan untuk menunjuk direksi dan memutuskan kebijakan besar perusahaan yang dapat memengaruhi kekayaan mereka. Secara teori persentase kepemilikan diatas 50\% (lima puluh persen) dianggap sebagai blockholder karena dianggap sebagai mayoritas dan dapat mengambil keputusan sepihak, namun fakta yang ada adalah kewenangan pemegang saham mayoritas dibatasi oleh undang-undang dan peraturan lain. Banyak negara menggunakan 5\% (lima persen) sebagai patokan pemegang saham dianggap sebagai blockholder hal ini lebih karena kewajiban dalam keterbukaan informasi, sedangkan bukti empirik (Holderness \& Sheehan, 1985) menjelaskan bahwa kepemilikan dianggap sebagai blockholder karena mendapatkan efek signifikan terkait berita positif atau negatif dari Perusahaan. Mayoritas penelitian tentang blockholder secara eksklusif berfokus pada persentase kepemilikan, padahal nilai investasi dapat dipertimbangkan sebagai dasar penentuan pemegang saham mana yang dianggap sebagai blockholder. Investasi pada Perusahaan besar pasti membutuhkan nilai yang sangat besar namun mendapatkan persentase kepemilikan yang sedikit, berbeda dengan investasi pada Perusahaan yang menengah atau kecil dimana nilai investasi yang besar akan mendapatkan persentase kepemilikan yang besar. Oleh sebab itu, nilai investasi dianggap penting (Edmans \& Holderness, 2017).

Perubahan atas peraturan tersebut dibuat sebagai upaya PT BEI untuk meningkatkan volume, kualitas transaksi, dan likuiditas atas perdagangan saham di bursa. Peraturan tersebut dianggap oleh banyak analis pasar modal dapat memberikan dampak positif karena semakin banyak saham beredar (free float) maka perdagangan 
saham diharapkan akan semakin likuid. Pasar dengan kondisi sempurna merupakan keadaan dimana surat berharga yang dimiliki dalam hal ini adalah saham dapat dikonversi menjadi bentuk yang lebih likuid yaitu kas ataupun sebaliknya dalam jumlah yang tidak terbatas secara instan tanpa memerlukan biaya apapun. Dengan demikian, pasar yang likuid merupakan pasar dengan biaya yang paling minimal untuk dapat melakukan konversi surat berharga menjadi kas ataupun sebaliknya. Likuiditas sendiri dalam pasar finansial merupakan gambaran dari alokasi sumber daya ekonomi yang efisien melalui modal dan risiko dari para calon investor, penyebaran informasi spesifik yang efektif, dan keefektivitasan dari kebijakan moneter dan stabilitas keuangan. Semakin rendah likuiditas dari suatu saham, maka akan semakin tinggi tingkat risiko premium (selisih antara market risk dengan risk free) yang diharapkan oleh investor atau calon investor.

\section{Metode Penelitian}

Penelitian ini berlangsung di bulan Januari-April 2020 dengan mengombinasikan data sekunder yang diperoleh dari beberapa sumber, seperti: datastream Thomson Reuters, laporan keuangan dan tahunan perusahaan yang dirilis dalam halaman resmi Perusahaan.

Penelitian ini berlangsung di bulan Januari-April 2020 dengan menggunakan data panel yang periode 2014 - 2018 dari seluruh Perusahaan yang terdaftar pada papan utama di Bursa Efek Indonesia. Data panel yang telah diteliti merupakan data sekunder (secondary data) yang diperoleh dari datastream Thomson Reuters dan laporan tahunan yang dipublikasikan pada media elektronik baik itu situs BEI ataupun situs resmi Perusahaan. Purposive sampling menjadi metode yang digunakan untuk pemilihan sampel yang mengambil kriteria dengan tujuan tertentu. Tujuan dari metode ini adalah agar data yang diteliti dapat menjawab rumusan masalah penelitian dengan hasil yang lebih representasif. Total sampel yang terpilih adalah sebanyak 225 (dua ratus dua puluh lima) Perusahaan dengan data sebanyak 20 (dua puluh) triwulan sehingga total data yang diolah adalah sebanyak 27.000 (dua puluh tujuh ribu) data. Berikut adalah distribusi sampel yang terpilih:

Tabel 1

Distribusi Sampel

\begin{tabular}{lcc}
\hline Kategori & Jumlah Perusahaan & Persentase \\
\hline Perdagangan & 60 & $27 \%$ \\
\hline Industri Dasar & 28 & $12 \%$ \\
\hline Properti & 25 & $11 \%$ \\
\hline Keuangan & 24 & $11 \%$ \\
\hline Konsumsi & 23 & $10 \%$ \\
\hline Pertambangan & 20 & $9 \%$ \\
\hline Infrastruktur & 17 & $8 \%$ \\
\hline Perkebunan & 10 & $4 \%$ \\
\hline Lain-lain & 18 & $8 \%$ \\
\hline Total & $\mathbf{2 2 5}$ & $\mathbf{1 0 0 \%}$ \\
\hline
\end{tabular}


Penelitian ini menggunakan kombinasi data time-series dan cross-section. Oleh karena itu, regresi data panel merupakan model regresi yang paling tepat untuk penelitian yang dilakukan. (Wooldridge, 2018) mengungkapkan langkah-langkah dalam menentukan model estimasi yang biasa dikenal dengan Fixed Effect Model ("FEM") dan Random Effect Model ("REM"). Metode estimasi yang digunakan dalam penelitian ini adalah uji Chow, Hausman, dan Breusch Pagan Lagrange. Hasil estimasi dianggap Best Linear Unlimited Estimator (BLUE) pada metode regresi data panel dari penelitian ini jika semua asumsi Gauss Markov terpenuhi, seperti: uji normalitas, uji multikolinearitas, uji heteroskedastisitas, dan uji autokorelasi.

Pengukuran likuiditas dalam penelitian ini menggunakan variabel: rasio likuiditas (Amihud, 2002), turnover (Lesmond, 2005); dan (Bekaert, Harvey, \& Lundblad, 2007), relative bid-ask spread (Li et al., 2014), dan depth (Rhee \& Wang, 2009). Oleh sebab itu, persamaan yang digunakan adalah:

$$
\begin{gathered}
\text { Ami i }_{i, t}=\beta_{0}+\beta_{1} \text { FF }_{i, t}+\beta_{2} \text { Size }_{i, t}+\beta_{3} \text { Sprd }_{i, t}+\beta_{4} \text { Tov }_{i, t}+\beta_{5} \text { Depth }_{i, t} \\
+\beta_{6} \text { Return }_{i, t}+\beta_{7} \text { RoA }_{i, t}+\varepsilon_{i, t}
\end{gathered}
$$

(Fang, Noe, \& Tice, 2009) dan (Nguyen, Duong, \& Singh, 2016) menjelaskan bahwa faktor-faktor spesifik perusahaan dalam hubungan dengan nilai perusahaan adalah sebagai berikut: rasio laba operasi terhadap harga (operating income to price "OIP"), rasio leverage keuangan ("leverage"), dan rasio laba operasi atas aset (operating income on assets - "OIOA"), dan ukuran perusahaan.

$$
\begin{aligned}
\text { FirmValue }_{i, t} & =\beta_{0}+\beta_{1} \text { Ami i }_{i, t}+\beta_{2} \text { Size }_{i, t}+\beta_{3} \text { OIP }_{i, t}+\beta_{4} \text { Lev }_{i, t}+\beta_{5} \text { OIOA }_{i, t} \\
& +\varepsilon_{i, t}
\end{aligned}
$$

Penelitian sebelumnya (Konijn, Kräussl, \& Lucas, 2011) menjelaskan bahwa penyebaran kepemilikan memiliki hubungan negatif dengan nilai perusahaan.

$$
\begin{aligned}
& \text { FirmValue }_{i, t}=\beta_{0}+\beta_{1} \text { FF F }_{i, t}+\beta_{2} \text { Ami i i,t }+\beta_{3} \text { Size }_{i, t}+\beta_{4} \text { OIP }_{i, t}+\beta_{5} \text { Lev }_{i, t} \\
& +\beta_{6} \text { OIOA }+\beta_{7} \text { Sprd }_{i, t}+\beta_{8} \text { Tov }_{i, t}+\beta_{9} \text { Depth }_{i, t}+\beta_{10} \text { Return }_{i, t} \\
& +\beta_{11} R o A_{i, t}+\varepsilon_{i, t}
\end{aligned}
$$

H1 : Penyebaran kepemilikan berkaitan dengan likuiditas yang lebih rendah

Free float adalah sejumlah saham yang dijual kepada publik pada saat perusahaan masuk ke pasar modal (Berk, Jonathan and DeMarzo, 2017) menjelaskan bahwa free float adalah jumlah saham yang sebenarnya tersedia untuk dijual. Saham tersebut tidak termasuk jumlah saham yang dimiliki oleh pemerintah, afiliasi, karyawan kunci (Ding et al., 2016), sedangkan definisi free float menurut Bursa Efek Indonesia adalah jumlah saham yang dimiliki oleh pemegang saham non pengendali dan non pengendali pemegang saham utama.

H2 : Likuiditas dikaitkan dengan nilai perusahaan yang lebih tinggi

Rasio Amihud Illiquidity banyak digunakan sebagai acuan dalam mengukur likuiditas karena kemudahan dan efektivitas dalam pengukuran. Namun demikian, 
terdapat asumsi penting yang harus dijaga agar rasio Amihud menjadi tolak ukur likuiditas yang valid. Perusahaan yang dipilih harus memiliki volume perdagangan pada waktu yang rentan. Dengan kata lain, jika tidak ada perdagangan sekaligus rentan, rasio Amihud tidak dapat ditentukan.

H3 : Penyebaran kepemilikan berkaitan dengan nilai perusahaan yang lebih rendah

(Tobin, 1969) menjelaskan bahwa alasan utama mengapa permintaan agregat dapat dipengaruhi oleh kebijakan keuangan dan dengan mengubah penilaian fisik aset menjadi biaya penggantian aset. Model yang digunakan dalam penelitian ini hanya ilustrasi dan dapat dikembangkan secara fleksibel. Rasio Tobin's Q telah banyak digunakan sebagai alat untuk mengukur nilai perusahaan dalam berbagai penelitian. Rasio Tobin's Q diukur dengan nilai pasar aset dibagi dengan nilai buku aset (market-tobook ratio) dan biasanya dihitung pada akhir tahun. Nilai pasar aset didefinisikan sebagai nilai pasar ekuitas ditambah nilai buku aset dikurangi nilai buku ekuitas dan dikurangi pajak tangguhan dalam laporan posisi keuangan.

Variabel kontrol - relative spread bid-ask (Santoso, 2012), turnover (Lesmond, 2005) dan (Bekaert et al., 2007), depth (Rhee \& Wang, 2009), imbal hasil saham (Ding et al., 2016), dan logaritma natural dari total asset (Fang et al., 2009); dan (Konijn et al., 2011) adalah seperangkat variabel kontrol untuk pengukuran likuiditas. Faktor spesifik perusahaan terdiri dari rasio rasio laba operasi terhadap harga (operating income to price - "OIP”), rasio leverage keuangan ("leverage"), dan rasio laba operasi atas aset (operating income on assets - "OIOA"), dan ukuran perusahaan (Fang et al., 2009); (Nguyen et al., 2016), dan pengembalian aset (Konijn et al., 2011).

\section{Hasil dan Pembahasan}

Pertama, penelitian ini mengumpulkan data dari aliran data Thomson Reuters dan melakukan proses regresi awal untuk menentukan apakah data tersebut berada dalam kisaran standar deviasi. Karena data yang kami dapatkan dalam penelitian ini tidak terdistribusi secara normal, penelitian ini dilakukan dengan proses "winsorization" untuk menangani pencilan dengan mengubah nilai data yang sangat tinggi menjadi nilai data tertinggi yang tidak dianggap sebagai pencilan. Penelitian ini menggunakan fungsi "winsor2" pada aplikasi STATA untuk mengubah pencilan dan menghasilkan nilai data baru dalam kisaran standar deviasi. Berikut tabel statistik deskriptif sebelum dan sesudah proses "winsorization":

\section{Tabel 2}

Definisi Variabel

\begin{tabular}{|c|c|}
\hline Variabel & Definisi \\
\hline \multicolumn{2}{|r|}{ Variabel Dependen } \\
\hline Firm & Nilai pasar aset dibagi dengan nilai buku aset yang diukur pada akhir tahun \\
\hline Value & $\begin{array}{l}\text { fiskal, di mana nilai pasar aset didefinisikan sebagai nilai pasar ekuitas } \\
\text { ditambah nilai buku aset dikurangi nilai buku ekuitas dikurangi pajak } \\
\text { tangguhan pada posisi keuangan }\end{array}$ \\
\hline \multicolumn{2}{|r|}{ Variabel Independen } \\
\hline
\end{tabular}


Ami : Rata-rata rasio nilai absolut tingkat pengembalian ke volume

\begin{tabular}{lll}
\hline \multicolumn{1}{c}{ Variabel Kontrol } \\
\hline Size & $:$ & Logaritma natural dari total aset \\
OIP & $:$ & Pendapatan operasional setelah depresiasi dibagi dengan nilai pasar ekuitas \\
Leverage & $:$ & Nilai pasar ekuitas dibagi dengan nilai pasar aset \\
OIOA & $:$ & Pendapatan operasional setelah depresiasi dibagi nilai buku aset \\
Sprd & $:$ & Logaritma dari perbedaan antara harga bid-ask \\
Tov & $:$ Logaritma volume perdagangan dibagi dengan rata-rata total ekuitas \\
Depth & $:$ Logaritma natural dari harga bid-ask dibagi dengan volume perdagangan \\
Return & $:$ Logaritma natural dari tingkat pengembalian \\
RoA & $:$ Logaritma laba bersih dibagi dengan aset \\
\hline
\end{tabular}

Tabel 3

Ringkasan Statistika (Sebelum dan Sesudah Winsorization)

\begin{tabular}{|c|c|c|c|c|c|c|c|c|c|c|c|c|c|c|}
\hline \multirow[t]{2}{*}{ Var } & \multicolumn{2}{|c|}{ Mean } & \multicolumn{2}{|c|}{ Median } & \multicolumn{2}{|c|}{ Std. Dev. } & \multicolumn{2}{|c|}{ Max } & \multicolumn{2}{|c|}{ Min } & \multicolumn{2}{|c|}{ Skew } & \multicolumn{2}{|c|}{ Kurt } \\
\hline & $*$ & $* *$ & $*$ & $* *$ & $*$ & $* *$ & $*$ & $* *$ & $*$ & $* *$ & $*$ & $* *$ & $*$ & $* *$ \\
\hline Firm Value & 1,44 & 1,69 & 1,09 & 1,11 & 1,04 & 1,89 & 8,30 & $\begin{array}{c}15,1 \\
2\end{array}$ & 0,00 & 0,34 & 2,89 & 4,11 & 10,48 & 19,36 \\
\hline FF & 0,32 & 0,32 & 0,30 & 0,30 & 0,18 & 0,18 & 1,00 & 0,88 & 0,00 & 0,02 & 0,67 & 0,58 & 0,34 & 0,00 \\
\hline Ami & $-0,04$ & $-2,96$ & 0,00 & $(2,93)$ & 0,27 & 0,69 & 0,01 & 0,00 & $-1,89$ & $-4,88$ & $-6,21$ & 0,35 & 36,62 & 1,60 \\
\hline Size & 29,33 & 12,75 & 29,28 & 12,71 & 2,07 & 0,74 & 34,89 & $\begin{array}{c}14,9 \\
6 \\
\end{array}$ & 0,00 & 10,99 & $-4,21$ & 0,30 & 61,74 & $-0,05$ \\
\hline OIP & 36,32 & 38,23 & 27,48 & 27,48 & 224,92 & 162,05 & $\begin{array}{c}2618 \\
80\end{array}$ & $\begin{array}{r}120 \\
9,88\end{array}$ & $\begin{array}{c}- \\
2883,69\end{array}$ & $-1622,11$ & $-2,40$ & $-1,47$ & 55,25 & 32,16 \\
\hline Leverage & 2,59 & 2,58 & 1,85 & 1,85 & 1,99 & 1,95 & 12,11 & $\begin{array}{c}11,3 \\
5 \\
\end{array}$ & 0,00 & 1,01 & 2,20 & 2,12 & 5,11 & 4,52 \\
\hline OIOA & 0,01 & 0,01 & 0,02 & 0,02 & 0,10 & 0,09 & 0,11 & 0,10 & $-0,95$ & $-0,89$ & $-7,78$ & $-8,19$ & 62,40 & 70,86 \\
\hline Sprd & 0,03 & 0,03 & 0,01 & 0,01 & 0,12 & 0,09 & 2,00 & 0,42 & $-2,00$ & $-2,00$ & $-9,16$ & $\begin{array}{c}- \\
12,06 \\
\end{array}$ & 202,5 & 290,76 \\
\hline Tov & 19,38 & 8,42 & 20,20 & 8,77 & 4,69 & 2,02 & 27,58 & $\begin{array}{c}11,7 \\
7\end{array}$ & 0,00 & 0,00 & $-0,86$ & $-0,80$ & 1,20 & 0,98 \\
\hline Depth & 14,28 & 14,29 & 14,00 & 14,00 & 2,94 & 2,86 & 23,37 & $\begin{array}{c}21,9 \\
2\end{array}$ & 0,00 & 0,00 & 0,08 & 0,19 & 0.59 & $-0,25$ \\
\hline Return & 0,01 & 0,01 & 0,01 & 0,01 & 0,11 & 0,10 & 0,73 & 0,50 & $-0,87$ & $-0,45$ & $-0,20$ & 0,14 & 6,86 & 3,72 \\
\hline RoA & 0,00 & $(4,89)$ & 0,00 & $(5,90)$ & 0,00 & 2,48 & 0,00 & 0,00 & 0,00 & $-8,33$ & 1,47 & 1,37 & 80,49 & 0,13 \\
\hline
\end{tabular}

Seperti terlihat pada tabel 2 dan 3, variabel yang mengalami perubahan dalam rentang standar deviasi adalah sebagai berikut: nilai perusahaan (dari 1,04 menjadi 1,89), Amihud Illiquidity $(0,27$ to 0,69$)$, logaritma natural dari total aset (dari 2,07) menjadi 0,74$)$; OIP (224,92 hingga 162,05$)$, leverage (1,99 hingga 1,95$)$, OIOA $(0,10$ hingga 0,09$)$, relative bid-ask spread $(0,12$ hingga 0,09$)$, logaritma natural dari turnover (4,69 hingga 2,02), logaritma natural dari depth (2,94 hingga 1,24), logaritma tingkat pengembalian saham $(0,11$ hingga 0,10$)$, dan logaritma tingkat pengembalian aset $(0,00$ hingga 2,48).

Kedua, penelitian ini melakukan proses regresi untuk menentukan model dan metode estimasi mana yang terbaik. Hasil regresi ditunjukkan dari tabel di bawah ini: 
Tabel 4

Model Regresi

\begin{tabular}{|c|c|c|c|c|c|c|c|}
\hline & Model 1 & Model 2 & Model 3 & & Model 1 & Model 2 & Model 3 \\
\hline \multirow[t]{2}{*}{ FF } & $-0.13^{*}$ & & -0.23 & Sprd & $\mathbf{- 0 . 5 8} * * *$ & & -0.16 \\
\hline & $(-2.17)$ & & $(-1.53)^{*}$ & & $(-10.92)$ & & $(-1.10)^{*}$ \\
\hline \multirow[t]{2}{*}{ Ami } & & & $\overline{-}$ & Tov & $-0.14 * * *$ & & 0.01 \\
\hline & & & $(-15.69)$ & & $(-38.96)$ & & $(0.58) *$ \\
\hline \multirow[t]{3}{*}{ Size } & $0.04 * * *$ & - & - & Depth & $\mathbf{0 . 0 3} * * *$ & & $-0.02 *$ \\
\hline & & $0.26 * * *$ & $\mathbf{0 . 7 2} * * *$ & & & & \\
\hline & (1.11) & & $(-9.62)$ & & (7.39) & & $(-1.96)^{*}$ \\
\hline \multirow[t]{2}{*}{ OIP } & & -0.00 & $\mathbf{0 . 0 0} * * *$ & $\begin{array}{l}\text { Retur } \\
\mathrm{n}\end{array}$ & $0.79 *$ & & $1.07 * * *$ \\
\hline & & $(-1.65)$ & $(4.94) *$ & & (17.66) & & $(8.71)^{*}$ \\
\hline \multirow[t]{2}{*}{ Lev } & & $0.05 * * *$ & $\begin{array}{c}-\overline{0} \\
0.05 * *\end{array}$ & RoA & $\mathbf{0 . 0 0} * * *$ & & -0.00 \\
\hline & & $(11.02)$ & $(-4.50) *$ & & (2.07) & & $(-1.26)^{*}$ \\
\hline OIO & & $0.20 * *$ & - & Const & -2.67 & 0.20 & $9.46 * * *$ \\
\hline \multirow[t]{2}{*}{ A } & & & $0.97 * * *$ & & & & \\
\hline & & (2.67) & $(-5.80)$ & & $(-5.42)$ & 0.37 & $(10.03)^{*}$ \\
\hline $\mathrm{N}$ & 4500 & 4500 & 4500 & & & & \\
\hline $\mathrm{R} 2$ & 0.33 & 0.04 & 0.11 & & & & \\
\hline \multicolumn{8}{|c|}{ Angka dalam tanda kurung adalah $\mathrm{t}$ statistic } \\
\hline \multicolumn{8}{|c|}{ Angka dalam tanda kurung dan tanda bintang adalah $\mathrm{z}$ statistik } \\
\hline & & Lege & da: $* \mathrm{p}<0$. & $5 ; * * \mathrm{p}$ & $01 ; * * * \mathrm{p}<$ & & \\
\hline
\end{tabular}

Tabel 5

Uji Chow

Model $1 \quad$ Model 2

Model 3

\begin{tabular}{lll}
\hline Prob $>F=0,0000$ & Prob $>F=0,0000$ & Prob $>F=0,0000$ \\
\hline$p$-value $<0,05$ & p-value $<0,05$ & p-value $<0,05$
\end{tabular}

Tabel 6

Uji Hausman

\begin{tabular}{ccc}
\hline Model 1 & Model 2 & Model 3 \\
\hline Chi2 $(7)=249,86$ & Chi2 $(4)=72,41$ & Chi2 $(11)=8,18$ \\
\hline Prob $>$ Chibar2 $=0,0000$ & Prob $>$ Chibar2 $=0,0000$ & Prob $>$ Chibar2 $=0,6974$ \\
\hline p-value $<0,05$ & p-value $<0,05$ & p-value $<0,05$ \\
\hline FEM & FEM & REM
\end{tabular}

Tabel 7

Uji Breusch Pagan Lagrange Multiplier

\section{Model 1 \\ Model 2 \\ Model 3}

Chi2 (7) $=15.477,38$

Chi2 (4) = 14.282,13

Chi2 (11) $=18.094,33$

Prob > Chibar2 $=0,0000$ p-value $<0,05$

REM

Prob $>$ Chibar $2=0,0000$ $\mathrm{p}$-value $<0,05$

REM

Prob $>$ Chibar $2=0,0000$ p-value $<0,05$

REM 
Berdasarkan tabel sebelumnya seperti pada tabel 6 (uji chow) didapatkan bahwa semua model sudah fit untuk fixed effect model. Tabel 7 (uji Hausman) menunjukkan bahwa fixed effect model cocok untuk model 1 dan 2, sedangkan random effect model cocok untuk model 3. Tabel 8 (Uji Breusch Pagan Lagrange Multiplier) menunjukkan random effect model cocok untuk semua model.

Ketiga, uji normalitas, uji multikolinearitas, uji heteroskedastisitas, dan uji autokorelasi dilakukan dalam penelitian ini untuk memastikan hasil yang diestimasi merupakan Best Linear Unlimited Estimator. Hasilnya ada pada tabel di bawah ini:

Tabel 8

Uji Multikolinearitas

\begin{tabular}{llllllllll}
\hline & $\begin{array}{l}\text { Firm } \\
\text { Value }\end{array}$ & Ami & FF & Size & RelSPRD & Turnover & Depth & Storet & RoA \\
\hline Firm Value & 1,0000 & & & & & & & \\
\hline FF & 0,0343 & 1,0000 & & & & & & \\
\hline Ami & - & - & 1,0000 & & & & & \\
& 0,2234 & 0,0037 & & & & & & \\
\hline Size & - & 0,1725 & - & 1,0000 & & & & \\
& 0,0015 & & 0,3014 & & & & & \\
\hline RelSPRD & - & - & 0,0046 & - & 1,0000 & & & \\
& 0,0406 & 0,1030 & & 0,1890 & & & & \\
\hline Turnover & 0,2372 & 0,2984 & - & 0,6296 & $-0,2428$ & 1,0000 & & & \\
& & & 0,2466 & & & & & \\
\hline Depth & 0,3625 & - & - & 0,4490 & 0,0066 & 0,3612 & 1,0000 & & \\
& & 0,0240 & 0,7377 & & & & & & \\
\hline Storet & 0,0109 & 0,0252 & 0,1674 & 0,0425 & 0,0064 & 0,0531 & 0,0352 & 1,0000 & \\
\hline RoA & - & - & 0,2016 & 0,0881 & 0,0055 & $-0,0978$ & - & - & 1,0000 \\
& 0,0257 & 0,0734 & & & & & 0,1970 & 0,0033 \\
\hline
\end{tabular}

Tabel 9

Uji Heteroskedasticitas

\begin{tabular}{ccc}
\hline Model 1 & Model 2 & Model 3 \\
\hline Chi2 $(225)=1.6 \mathrm{e}+05$ & Chi2 $(225)=3.6 \mathrm{e}+06$ & Chi2 $(225)=8.4 \mathrm{e}+06$ \\
\hline Prob $>$ Chibar2 $=0,0000$ & Prob $>$ Chibar2 $=0,0000$ & Prob $>$ Chibar2 $=0,0000$ \\
\hline $\mathrm{p}$-value $<0,05$ & $\mathrm{p}$-value $<0,05$ & $\mathrm{p}$-value $<0,05$ \\
& Tabel 10 & \\
& Uji Auto Korelasi & Model 3 \\
\hline & Model 2 & $\mathrm{F}(1,224)=2,905$ \\
\hline Model 1 & $\mathrm{F}(1,224)=3407,657$ & Prob $>$ Chi2 $=0,0000$ \\
\hline $\mathrm{F}(1,224)=560,940$ & Prob $>$ Chi2 $=0,0000$ & $\mathrm{p}$-value $<0,05$ \\
\hline Prob $>$ Chi2 $=0,0000$ & $\mathrm{p}$-value $<0,05$ &
\end{tabular}

A. Pengaruh dan Hubungan Penyebaran Kepemilikan terhadap Likuiditas

Model pertama dalam penelitian ini adalah menguji hipotesis penyebaran kepemilikan terhadap likuiditas dengan dugaan penyebaran kepemilikan memiliki hubungan negatif dengan pengaruh signifikan terhadap likuiditas. Berdasarkan hasil 
dari 225 perusahaan yang terdaftar di Bursa Efek Indonesia, model estimasi terbaik adalah fixed effect model, penyebaran kepemilikan memiliki hubungan negatif dan berpengaruh signifikan terhadap likuiditas. Artinya semakin tinggi persentase free float perusahaan tercatat maka perdagangan saham di pasar modal semakin tidak likuid. Hasil regresi menjelaskan bahwa free float dapat memengaruhi likuiditas saham perusahaan dan penjelasan potensi hubungan ini berasal dari strategi buyhold dan informasi asimetris yang menyebabkan investor (biasanya lembaga asing dan/ atau perusahaan keluarga) untuk melakukan transaksi (Heflin \& Shaw, 2000) dan (Rhee \& Wang, 2009).

B. Pengaruh dan Hubungan Likuiditas terhadap Nilai Perusahaan

Model kedua dalam penelitian ini adalah menguji hipotesis likuiditas terhadap nilai perusahaan dengan dugaan bahwa likuiditas berpengaruh signifikan dan memiliki hubungan negatif terhadap nilai perusahaan. Berdasarkan hasil penelitian terhadap 225 perusahaan yang terdaftar di Bursa Efek Indonesia, model estimasi terbaik adalah fixed effect model, likuiditas berpengaruh signifikan dan berpengaruh positif terhadap nilai perusahaan. Faktor - faktor risiko yang dapat memengaruhi likuiditas terhadap imbal hasil Perusahaan antara lain: investor ingin diberi kompensasi karena memiliki sekuritas yang menjadi tidak likuid ketika pasar secara umum menjadi tidak likuid, investor bersedia menerima pengembalian aset yang lebih rendah dengan pengembalian tinggi ketika pasar tidak likuid, dan kesediaan investor untuk menerima pengembalian yang diharapkan lebih rendah dari sekuritas likuid di pasar yang menurun. Temuan ini konsisten dengan penelitian sebelumnya (Amihud, 2002) dan (Acharya \& Pedersen, 2005) yang memberikan bukti adanya korelasi positif antara likuiditas dengan imbal hasil saham perusahaan.

C. Pengaruh dan Hubungan Penyebaran Kepemilikan terhadap Nilai Perusahaan melalui Likuiditas

Model ketiga dalam penelitian ini adalah menguji hipotesis penyebaran kepemilikan terhadap nilai perusahaan dengan dugaan penyebaran kepemilikan berpengaruh signifikan dan negatif terhadap nilai perusahaan melalui likuiditas. Berdasarkan hasil penelitian terhadap 225 perusahaan yang terdaftar di Bursa Efek Indonesia, model estimasi terbaik adalah random effect model dimana penyebaran kepemilikan memiliki pengaruh yang signifikan dan berkorelasi negatif dengan nilai perusahaan melalui likuiditas. Seperti yang telah disebutkan di atas, karena persentase free float berkorelasi negatif dengan likuiditas, hal tersebut menyebabkan perputaran di pasar modal mengalami penurunan nilai yang mengakibatkan dampak buruk bagi kinerja perusahaan. Temuan ini konsisten dengan penelitian sebelumnya (Konijn et al., 2011) yang menyajikan hubungan negatif antara penyebaran kepemilikan dan nilai perusahaan. 


\section{Kesimpulan}

Berdasarkan penelitian terdahulu terkait hubungan antara free float terhadap likuiditas, free float terhadap nilai Perusahaan, dan likuiditas terhadap nilai Perusahaan, hasil dari masih bersifat tidak konklusif dimana para peneliti ada yang melaporkan hubungan negatif dan positif atas hubungan masing-masing variabel. Free float berpengaruh negatif terhadap likuiditas saham Perusahaan. Hasil pengujian menunjukkan bahwa makin tinggi tingkat free float tidak berbanding lurus dengan tingginya perdagangan saham. Oleh sebab itu, dapat disimpulkan bahwa keputusan Nomor: KEP 00059/BEI/07-2019 pada tanggal 22 Juli 2019 yang bertujuan untuk meningkatkan transaksi perdagangan tidak terbukti dapat menaikkan tingkat likuiditas saham Perusahaan. Likuiditas berpengaruh positif terhadap nilai Perusahaan. Hasil pengujian menunjukkan bahwa variabel rasio laba operasi dibagi dengan nilai buku aset (OIOA) dan leverage berpengaruh positif terhadap nilai Perusahaan. Hal ini menunjukkan bahwa perusahaan yang memiliki performance yang baik cenderung memiliki likuiditas yang lebih tinggi. Free float berpengaruh negatif terhadap nilai Perusahaan. Hasil pengujian menunjukkan bahwa hampir seluruh variabel (Amihud Illiquidity, Size, Leverage, OIOA, relative bid-ask spread, depth, dan RoA) berpengaruh negatif terhadap nilai Perusahaan.

PT Bursa Efek Indonesia ("BEI") selaku pengawas emiten dipasar modal diharapkan dapat mempertimbangkan kebijakan lain atau membuat kebijakan yang secara integral dapat meningkatkan efisiensi pasar modal di Indonesia agar semakin likuid. Berdasarkan penelitian, penetapan jumlah minimum free float belum dapat meningkatkan transaksi jual - beli saham di bursa. Saham yang likuid juga belum tentu memberikan imbal hasil positif bagi investor. Oleh sebab itu, para calon investor disarankan untuk membangun portofolio saham pada keranjang yang berbeda-beda dengan mengombinasikan berbagi macam jenis industri serta melakukan evaluasi terhadap saham yang akan dibeli. Berdasarkan kesimpulan dan keterbatasan yang dialami dalam penelitian, saran yang dapat diberikan kepada peneliti selanjutnya adalah mengembangkan model penelitian yang lebih komprehensif dengan mempertimbangkan isu endogenitas. 


\section{BIBLIOGRAFI}

Acharya, Viral V, \& Pedersen, Lasse Heje. (2005). Asset pricing with liquidity risk. Journal of Financial Economics, 77(2), 375-410. Google Scholar

Amihud, Yakov. (2002). Illiquidity and stock returns: cross-section and time-series effects. Journal of Financial Markets, 5(1), 31-56. Google Scholar

Bekaert, Geert, Harvey, Campbell R., \& Lundblad, Christian. (2007). Liquidity and expected returns: Lessons from emerging markets. The Review of Financial Studies, 20(6), 1783-1831. Google Scholar

Berk, Jonathan and DeMarzo, Peter. (2017). Corporate Finance: The Core (Fourth Edi). Global Edition, Pearson Education.

Edmans, Alex, \& Holderness, Clifford G. (2017). Blockholders: A survey of theory and evidence. The Handbook of the Economics of Corporate Governance, 1, 541-636. Google Scholar

Fang, Vivian W., Noe, Thomas H., \& Tice, Sheri. (2009). Stock market liquidity and firm value. Journal of Financial Economics, 94(1), 150-169. Google Scholar

Heflin, Frank, \& Shaw, Kenneth W. (2000). Blockholder ownership and market liquidity. Journal of Financial and Quantitative Analysis, 35(4), 621-633. Google Scholar

Holderness, Clifford G., \& Sheehan, Dennis P. (1985). Raiders or saviors? The evidence on six controversial investors. Journal of Financial Economics, 14(4), 555. Google Scholar

Konijn, Sander J. J., Kräussl, Roman, \& Lucas, Andre. (2011). Blockholder dispersion and firm value. Journal of Corporate Finance, 17(5), 1330-1339. Google Scholar

Lesmond, David A. (2005). Liquidity of emerging markets. Journal of Financial Economics, 77(2), 411-452. Google Scholar

Li, Haitao, Chung, Roger Yat Nork, Wei, Xiaolin, Mou, Jin, Wong, Samuel Yeung Shan, Wong, Martin Chi Sang, Zhang, Dan, Zhang, Yingji, \& Griffiths, Sian. (2014). Comparison of perceived quality amongst migrant and local patients using primary health care delivered by community health centres in Shenzhen, China. BMC Family Practice, 15(1), 1-7. Google Scholar

Nguyen, Trang, Duong, Huu Nhan, \& Singh, Harminder. (2016). Stock market liquidity and firm value: an empirical examination of the Australian market. International Review of Finance, 16(4), 639-646. Google Scholar

Rhee, S. Ghon, \& Wang, Jianxin. (2009). Foreign institutional ownership and stock market liquidity: Evidence from Indonesia. Journal of Banking \& Finance, 33(7), 
Penyebaran Kepemilikan, Likuiditas, dan Nilai Perusahaan: Bukti Dari Indonesia

1312-1324. Google Scholar

Santoso, Youngkie. (2012). Pengaruh asimetri informasi terhadap praktik manajemen laba pada perusahaan manufaktur di BEI. Berkala Ilmiah Mahasiswa Akuntansi, 1(3), 82-88. Google Scholar

Tobin, James. (1969). A general equilibrium approach to monetary theory. Journal of Money, Credit and Banking, 1(1), 15-29. Google Scholar

\section{Copyright holder:}

Syaipul Malik Ibrahim, Dewi Hanggraeni (2021)

First publication right:

Syntax Literate: Jurnal Ilmiah Indonesia

This article is licensed under:

(c) (i) (?) 